\title{
The rehabilitation of former Soviet military sites in Hungary
}

\author{
KRISZTA KÁDÁR ${ }^{1}$
}

\begin{abstract}
This paper focuses on the current status and future possibilities of the regeneration of former Soviet military sites in Hungary. As part of our research a nationwide survey was conducted in order to determine the location, size and present function of such military sites. In addition, empirical research was carried out in six selected medium size cities (county seats). After the introduction of our methodology, the paper briefly presents the state-of-the-art of research on brownfield sites in Hungary, subsequently, the results of our survey are introduced. On the basis of the analysis, we discuss the following aspects: factors of successful rehabilitation and factors that - against the expectations - did not contribute to the quick and successful renewal of these urban sites.
\end{abstract}

Keywords: brownfield regeneration, rehabilitation of military sites, Soviet military sites, functional conversion, Hungary

\section{Introduction}

Similarly to other post-socialist countries, after the change of regime, industrial and military sites have become excessively underused in Hungary (WoodWARD, R. 2004; SPYRA, W. and Katzsch, M. 2007). This was caused by various reasons e.g. by the fall in industrial production, the restructuring of the military system and the withdrawal of the Soviet troops. These areas have often become brownfields, and only a few of them have been converted to permanent use until most recently. Even though the Hungarian Academy of Sciences has already conducted general brownfield researches in Hungary, little information has been made available so far regarding the civil use, the new functions and the rehabilitation of Soviet military sites.

In the last twenty years, the transformation of military sites in Hungary remained limited, not least because the rehabilitation of these sites did not

\footnotetext{
${ }^{1}$ State Audit Office of Hungary, H-1052 Budapest, Apáczai Csere J. u. 10.

E-mail: kriszta.kadar@t-online.hu
} 
have high priority in urban regeneration policies. This can be partly explained by the fact that EU and Hungarian policy documents for regional and urban development apply a relatively narrow interpretation of brownfield territories. The category of brownfield includes mainly urban areas previously utilised for industrial and mining purposes, whereas former military sites and areas abandoned by traffic are generally not included. The EU has supported the utilisation of former industrial (mining) and military brownfields by various initiatives and programs (Ferber, U. et al. 2006; Grimski, D. and Ferber, U. 2001; KÁDÁr, K. 2009; KäLberer, A. 2005). However, Hungary could not essentially receive funds from the sources for the conversion of military areas.

In this study the conversion of Soviet military sites in Hungary and its obstacles are discussed. First we briefly introduce our research methodology and the problems related to brownfields. Then the history of the occupation of Hungary by Soviet troops and their withdrawal is summarised. In the analytical part the typical types of the former Soviet military sites and the results of our empirical research conducted in six Hungarian county seats are presented. On the basis of empirical research we want to highlight the new functions that the former military sites gained after the withdrawal of Soviet troops and their underpinning factors.

\section{Research methodology}

Information on military sites is difficult to acquire even today as there was no systematic data collection in the field and authorities possessing such information are difficult to approach. Therefore, a significant number of former Soviet military sites have been omitted from Hungarian documents aiming at mapping brownfields and analysing their utilisation. Similarly, documents of urban development (e.g. ICDS - Integrated City Development Strategy, economic development programs, e.g. Euró-Régió 2008. - HHP Contact, 2008) list only some of the former Soviet and Hungarian military sites.

The information about the exact location and size of former Soviet sites in scientific publications or internet websites is also quite poor. Either incomplete information or only data on special segments of the problem are available (e.g. NAGY, Á. 2003; IUCN 1996). Therefore, during our research first we had to perform own data collection through fieldwork, interviews and analysis of secondary data derived from archives and scientific literature (Altman, J. et al. 1998; BARTA, Gy. 2007; Csapody, T. 2000; Csendes, L. 1998a,b; Gyốri, R. 2006; NAGY, Á. 2003; RÁNKI, Gr. 1976; SÁGI, J. 2006). After the careful analysis of available publications we carried out empirical research in the county seats using different types of questionnaires. In addition we made interviews at the local government offices with the senior architect or his/her fellow-workers. Through questionnaire survey we could collect information about the rehabilitation of military barracks in the Hungarian county seats. 
Due to the lack of necessary information some sites were assessed through on-site surveys. Based on the acquired data a map was prepared illustrating the locations of the Soviet garrisons all over the country. We also assessed the changes in the use and functions of the former Soviet sites, which is the first comprehensive analysis of all former Soviet military sites in Hungary. As a part of our research, another type of questionnaire was sent out to all concerned local municipalities. The questionnaire survey revealed that information is available only for about 55 percent of all the sites. It is not surprising that different institutions and organisations lack relevant information in Hungary since the location, the capacity and the functions of Soviet (and also Hungarian) military sites were top secret before the change of regime.

\section{Challenges of brownfield areas in Hungary}

Due to deindustrialisation a significant amount of brownfield lands have been produced in Europe since the 1960s and 1970s. After the collapse of communism deindustrialisation also speeded up considerably in post-socialist cities as part of economic restructuring (Photo 1). Problems of brownfield areas have

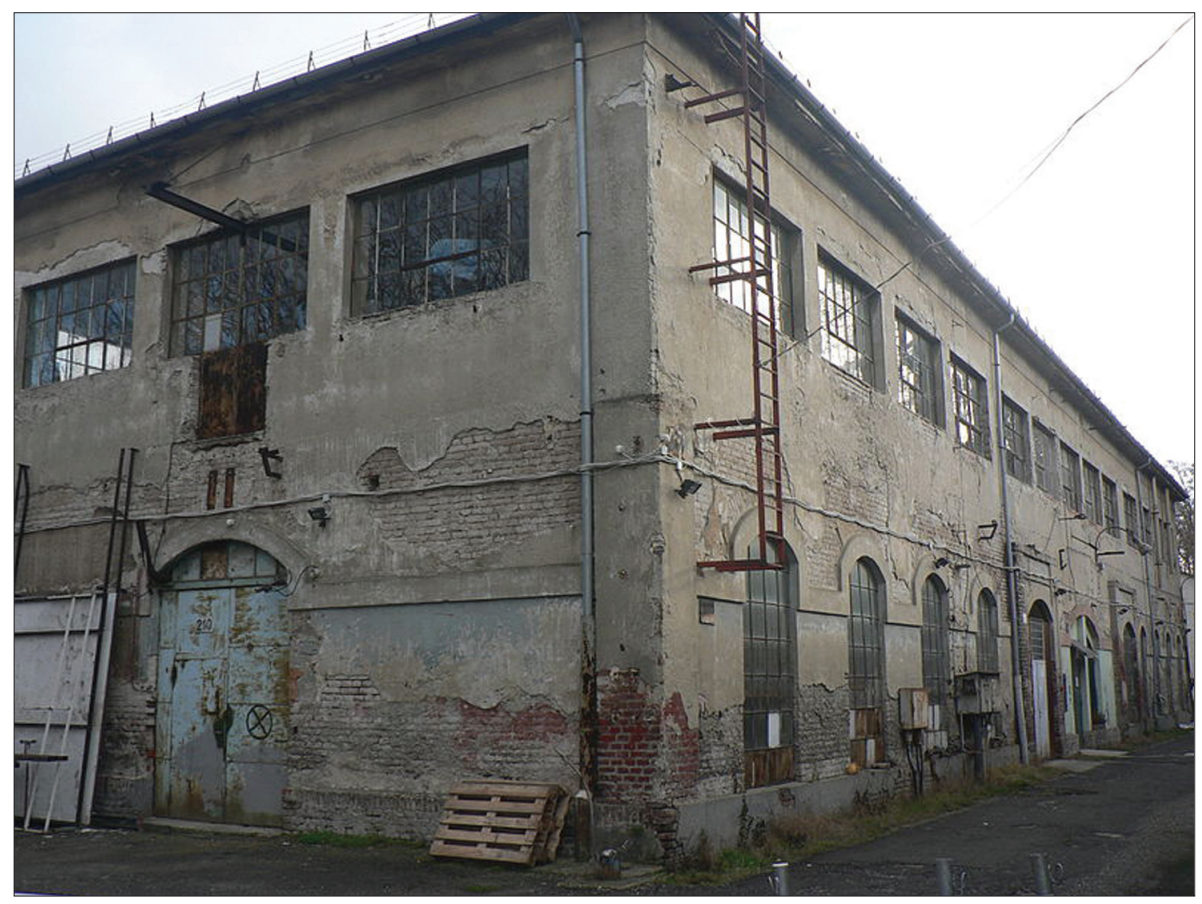

Photo 1. Brownfield area in the Hajógyár Island, Budapest. Source: internet 
been aggravated by former military and transport properties becoming empty both in Western and Eastern Europe (Oliver, L. et al. 2005; Lux, G. 2009; BARTA, GY. 2002; ERDôsI, F. 2009; KÁDÁR, K. 2011a).

The Centre for Regional Studies of the Hungarian Academy of Sciences defined in a seminal volume that brownfields are ex-industrial areas that are not used efficiently (underutilised) and are occasionally vacant (BARTA, Gr. 2004). Also the under-utilised or abandoned railway areas and the vacated military sites fall under this definition. Brownfield areas have negative effects on their environment, the surrounding communities, and their utilisation is also difficult. Their successful rehabilitation may contribute to increasing urban competitiveness, the improvement of the quality of urban life and it can decrease the crowding of cities (BARTA, Gr. 2003; JANin, C. and Andres, L. 2008).

The EU does not have exact data on the size of brownfield areas inside the European Union, basically due to the lack of consistent terminology. The Eurostat has not either published any information concerning the topic (until the end of 2010), although several programmes have been initiated in the last decades to handle the problem. Even though we do not have exact data, the survey of Ferber, U. et al. (2006) has revealed that approximately 1 million hectares of brownfield lands are to be found in 11 EU countries.

Since the change of regime new enterprises in Hungary have primarily preferred greenfield investments, meaning that the investments were mostly realised on vacant areas withdrawn from agricultural production (GYôRI, R. 2006). This is due to the fact that greenfield investments have been more cost-effective in Hungary than brownfield investments, since in the latter case some surveying, environmental release, demolition, cleaning and renovation or preservation of the existing buildings (e.g. having industrial historical significance) are necessary.

Successful brownfield regenerations of the last twenty years have been concentrated mainly in inner city areas in Hungary (BARTA, GY. 2002). The demand for land has been lower in the countryside, in former industrial or suburban areas. The analysis of greenfield and brownfield investments in regional centres shows that the possibilities of brownfield area development were not at all exploited by cities mainly due to the nearly unlimited amount of greenfield lands (GYốRI, R. 2006). However, in order to promote sustainable development, reutilisation of brownfields must be coupled with incentives, land-use policies and regulations that encourage investors to choose brownfield areas over greenfield locations. The goal is to maintain compact city land-use by enhancing the recycling of run-down and unused areas within cities and retaining green spaces that prevent settlements from urban sprawl. The unregulated development of greenfield sites decrease the share of green areas and other recreational functions and may decrease the ratio of areas that can be utilised in the future. 


\section{Former Soviet military sites in Hungary}

The aim of this study is to present the state of the art of rehabilitation of the former Soviet military areas in Hungary, as special segments of brownfield areas. The main difference between military brownfield areas and others is that their functional change does not stem from economic reasons or structural changes, but from political reasons. After the Cold War large scale military areas became evacuated and abandoned both in the countries of the NATO and the Warsaw Pact, as a consequence of the change in the global geopolitical system, and the subsequent the withdrawal of the American and Soviet troops. The evacuation was not only the consequence of consolidation and arms reductions: in some countries also the accession to the NATO resulted in the closure of several military and strategic facilities used previously by the national armies (Altman, J. et al. 1998). Some of them were passed into the ownership of local municipalities; others became the propriety of public institutions or churches, and the remaining part, whose renovation was the fastest, got into private ownership.

The rehabilitation of unused military areas caused a problem not only in countries of the former communist bloc, struggling with the lack of finances, but also in the wealthier Western European states. That is why more initiatives were launched in the EU in the last decade focusing especially on the rehabilitation and functional change of brownfield territories including military areas.

In the literature and internet sources we mainly find information about the conversion of former military sites of NATO member states. Information regarding the transformation of Soviet military sites in former state-socialist countries is scarce. Rare exceptions are the Soviet military sites in the former GDR, and especially in Brandenburg region, which was severely affected by the occupation of the Soviet army. After the withdrawal of Russian troops Brandenburg had to deal with the rehabilitation of several hundreds of polluted and abandoned sites (Kádár, K. 2009; GANSER, R. and Williams, K. 2007; Vogt, R. 2006; Millar, K. 2003; Kälberer, A. 2005).

The geographical distribution of Soviet troops in Hungary before 1991

Soviet troops invaded Hungary during World War II in autumn 1944 (Photo 2) and they left the country after 47 years in June 1991. Very little information is available about the military and political reasons for placing Soviet military sites into certain cities in Hungary. Data are mostly available about the Hungarian army and its restructuring, and these are to be found in the Institute and Archives of Military History. 


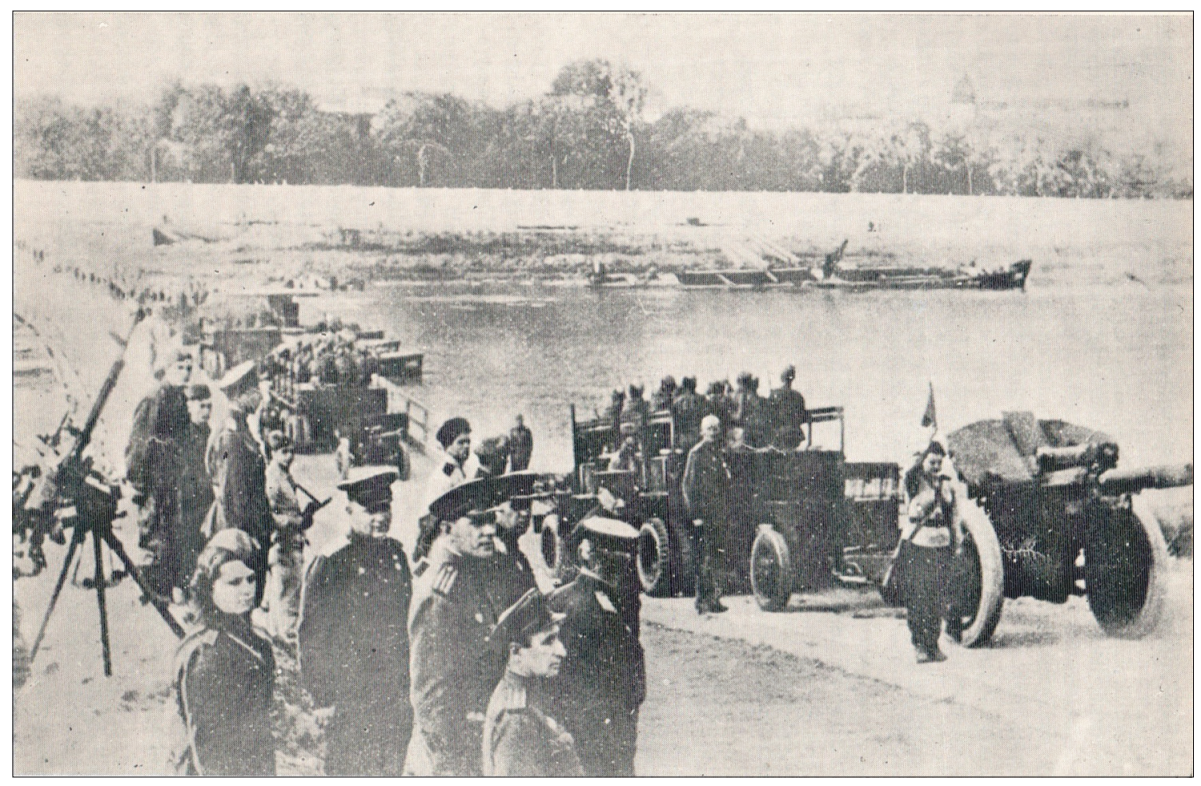

Photo 2. Soviet troops crossing the Tisza river in 1944. Source: internet

In the first phase of withdrawal the Soviet Army withdrew 22 troops from Hungary: an armoured troop, a descent storming battalion, a chemical protection battalion, a military officer training school and other units (HомоR, Gr. 2009; HoRváTH, M. 2003; KÁDÁR, K. 2011b). The number of soldiers stationed in Hungary was decreased by 10,000 soldiers and 4,000 civilians also left the country.

After this first step 11 garrisons and several accommodation buildings got into Hungarian ownership. According to the information by colonel-general Burlakov, the accommodation buildings measured 950 hectares overall. Besides this, there were 850-900 flats, 19 military quarters, 13 canteens, 200 vegetable stores, depositories and other areas. 400 sites out of these had been built by the Southern Group of the Red Army (Veszprém Megyei Napló, 1989).

On Figure 1 we indicated the settlements where Soviet military sites were operating between 1945 and 1990 according to the available documents. Every settlement is indicated by a point independently from the number of sites and the size of the garrison. The number of garrisons whose activity had been ceased before 1990 is 30 . Altogether there are at least 108 known settlements in the country where Soviet soldiers have stationed up to the change of regime (Номов Gy. 2009; Institute and Archives of Military History 2006)².

\footnotetext{
${ }^{2}$ If we take into account neighbouring settlements where the boundaries of Soviet garrisons expanded, 13 more settlements can be added to the list.
} 


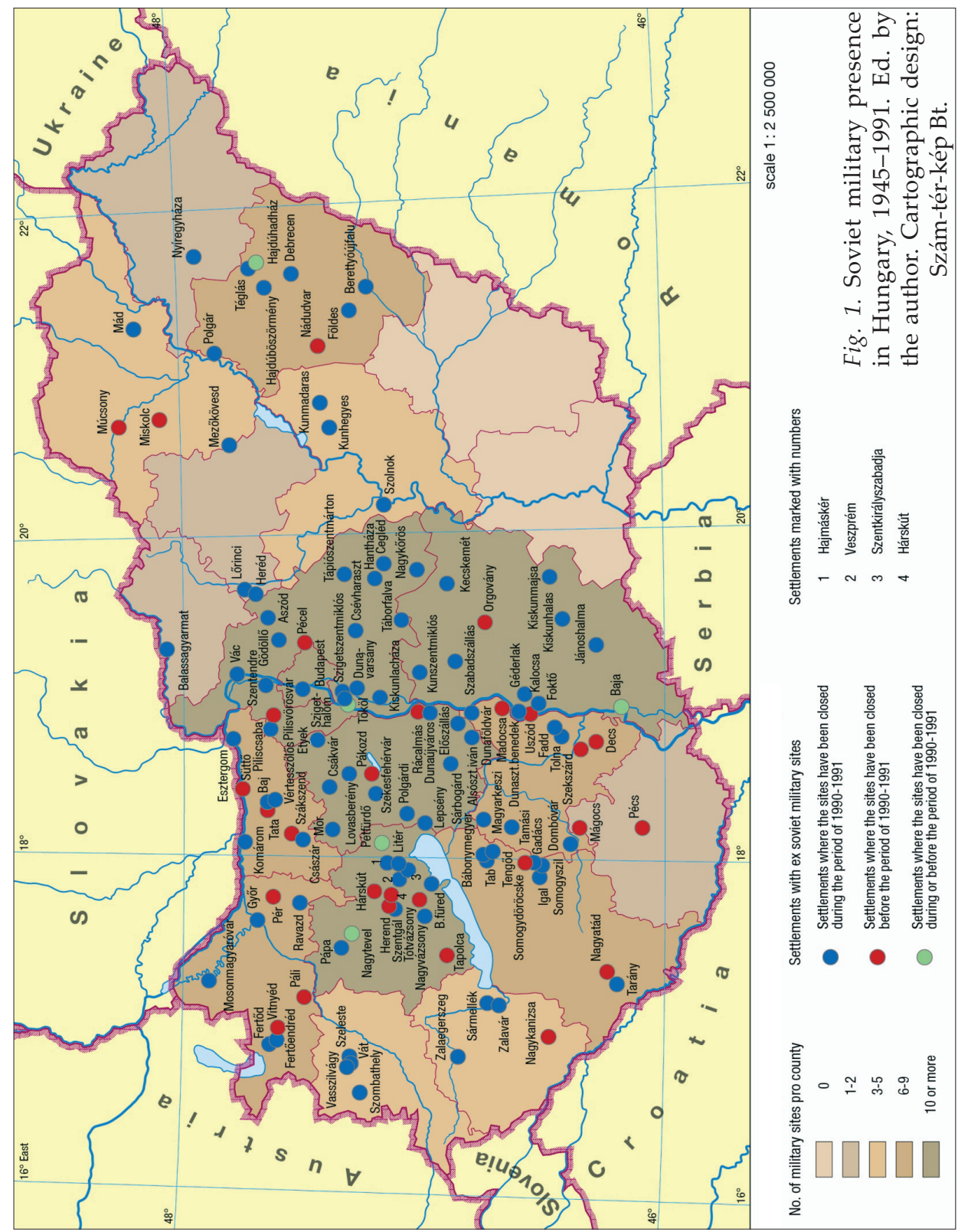


The map clearly shows that the presence of Soviet military forces affected most intensively Central Transdanubia and Central Hungary (Budapest and Pest county) and it was least dominant in Southeast Hungary. The border zones with former Czechoslovakia and the Soviet Union (Ukraine) in Northern Hungary, with Romania in Eastern Hungary, and with Yugoslavia in the South were also sparsely settled by the Soviet Army. However, higher concentration of Soviet military sites could be recorded around Debrecen. In Southeast Hungary the Soviets troops stationed only in four cities, in Kecskemét, Szolnok, Békéscsaba and Szeged. Other large areas like the Jászság or the region around the Lake Tisza remained vacant.

The occurrence of Soviet garrisons and sites is surprisingly dense in other areas of Hungary, for example in the area of Balaton Highlands and Székesfehérvár and its surroundings, around the middle part of the Danube (e.g. Dunaföldvár, Paks and Kalocsa), the Western part of Pest county and the environs of Gerecse and Vértes mountains (e.g. Komárom, Tata, Tatabánya, Oroszlány etc.) The Soviet forces appeared in several settlements along the Danube, whereas their presence concerned far fewer settlements in the Eastern part of the country, i.e. the region between the Danube-Tisza Interfluves than in Transdanubia.

The surveying and the estimation of environmental damages left behind by the Soviet troops had started before the complete withdrawal of all Soviet troops (NAGY, Á. 2005). Experts considered soil and water pollution by carbon-hydrogen the most severe. Furthermore, the amount of communal, operational and constructional waste stored up in accommodation buildings could be regarded significant. More surveys and environmental tests of former Soviet properties have been conducted since 1990 (IUCN 1996, VITUKI 2005). For the sake of damage elimination and the installation of the planned monitoring systems, a list of liabilities for environmental remediation was made regarding the properties belonging to State Privatization and Holding Company (ÁPV Rt.).

Based on government decrees, the environmental status surveys of former Soviet sites were conducted by the state. Within the scope of a midterm programme for eliminating the caused environmental damages, the most significant damages had to be prevented. As a result of the ÁPV Rt. launched "Former Soviet Real Estate Programme" as part of the National Environmental Remediation Programme, there were examinations on 9 sites and there was technical intervention on 25 sites, while 3 sites were subject to monitoring (Almássy, E. 2002). Summarising the damage caused by the Soviets, the environmental and natural damage amounted to HUF 66 billion. 171 garrisons with 6,000 buildings, occupying 46,000 hectares of land in 340 settlements were claimed to be contaminated (Photo 3).

Different sources provide different statistics about the evacuated Soviet sites. According to Csapody (2000) the Soviet Army was stationing with 


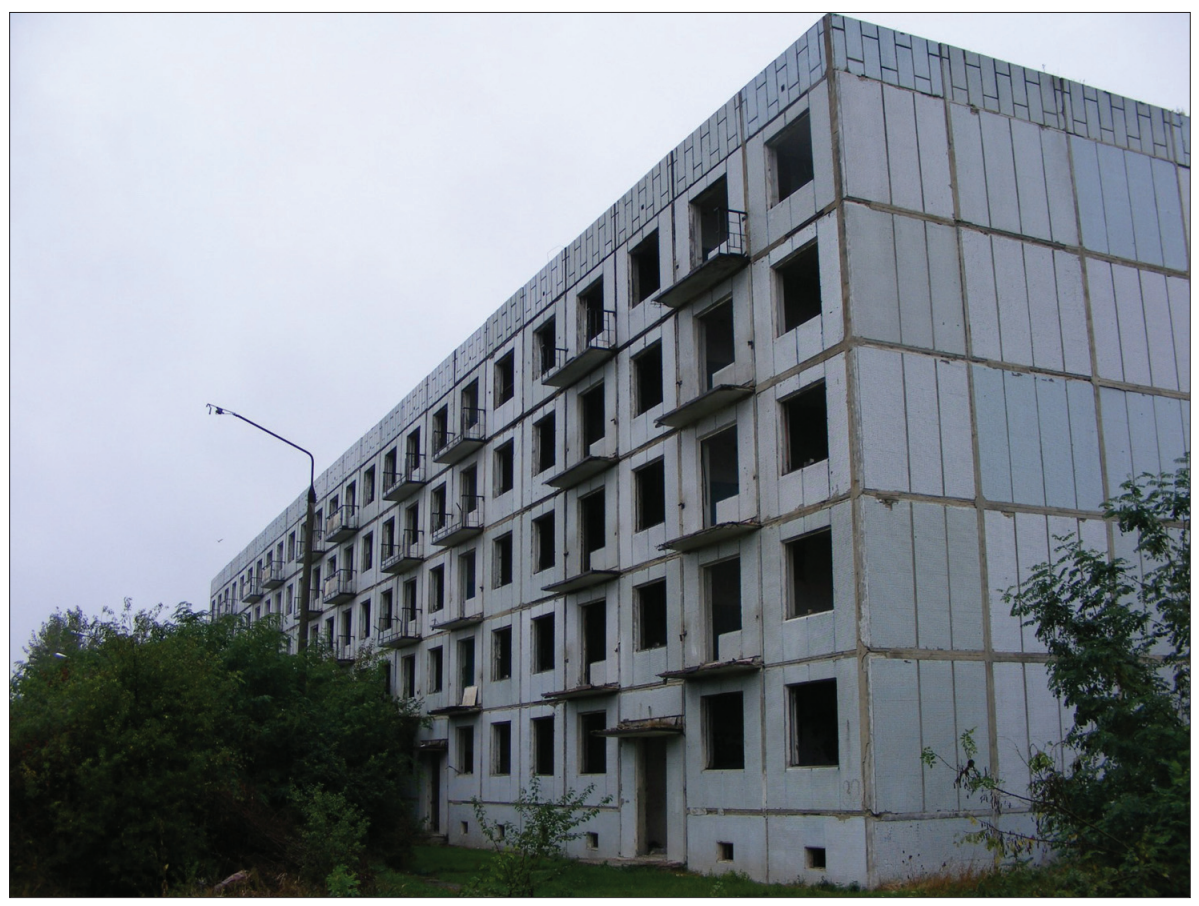

Photo 3. Former Soviet military flats in Szolnok (Photo: KÁdÁr, K.)

around 55,000 soldiers and approximately 10,000 civilians on 288 sites, in 104 settlements of Hungary. Based on the research of the National Environmental Remediation Programme made by VITUKI Kht. (NAGY, Á. 2005) 171 former Soviet sites were found in the country. Homor (2009) mentions in his book that 100,380 Soviet citizens left the country, including 44,668 soldiers, leaving 94 garrisons vacant. In these garrisons 328 properties were used by the Soviets.

Based on our research it can be stated that the Soviet army used at least 342 sites during their stay between 1945 and 1990, in at least 108 settlements. 13 more settlements can be added to the list, which are smaller settlements neighbouring the core settlements of the garrisons, like Somogydöröcske near Igal, or Fertőendréd near Fertőd etc. Thus, the number of settlements where Soviet Army stationed may reach 121 , which exceeds the data published so far.

\section{The reutilisation of former Soviet properties}

In 1990 new directives for utilisation of Soviet properties becoming vacant were worked out in Hungary, which was sent out to the presidents of the councils 
in each concerned settlement. Later in this year the committee supervising the withdrawal of Soviet troops and the committee coordinating the distribution of sites were contracted, and the new committee started the utilisation project according to the recommendations of the councils. Decision was made that those properties which were no subject of demand could be reutilised by the state. In these cases the Ministry of Interior negotiated with the Ministry of Welfare and the Ministry of Environmental Protection about the way of utilisation. In March 1991 the government announced that the reutilisation of the former Soviet properties would start in 14 settlements and the properties would be transferred to local the municipalities free of charge (Homor, Gy. 2009).

Utilisation was regulated by a government decree in 1992, which stated that utilisation became the responsibility of the Hungarian Property Management Organisation. The form of utilisation included the sale, the handing over free of charge, the leasing, the hypothecation and the passing over of the real estate to a company on the basis of the regulation. In the case of selling or leasing, the local municipality had the right of pre-emption or pre-leasing, however, the law stipulated that in the case of properties utilised by the Hungarian Property Management Organisation, the new owner was liable for environmental remediation, reutilisation and mapping. The properties could be utilised through an application or as a handing over free of charge. Plans for utilisation usually concerned the building of flats. This could be easily realised in the case of properties occupied by the Soviets but built by the Hungarians, however, properties built by the Soviets could be sold only following the signing of an intergovernmental agreement. Approximately 5 percent of Soviet sites got into the ownership and use of the Hungarian Army, and another part of them got into private ownership shortly after the evacuation - these were, on the one hand, buildings in adequate conditions that could be easily sold and cost-efficiently occupied, and on the other hand, areas that could be easily utilised for economic purposes. Based on their original functions the Soviet military sites could be divided into three groups (Table 1).

First the concerned settlements were contacted with a questionnaire in autumn 2011 in order to find out reuse of former Soviet site(s). Local municipalities could potentially give three answers concerning utilisation:

1. utilisation has already been finished,

2. it has partly been implemented,

3. it has not started yet.

The survey provided the following results: 61 local municipalities returned the sheet out of the 108 (56\%). Based on the answers we could obtain information about 188 sites out of the 342. The answers partly showed that some of the municipalities did not even know about the fact that once a Soviet site was located on their territory. The reuse was already finished in 32 percent of the 188 sites; it was partly finished in 26 percent and was not started in 18 


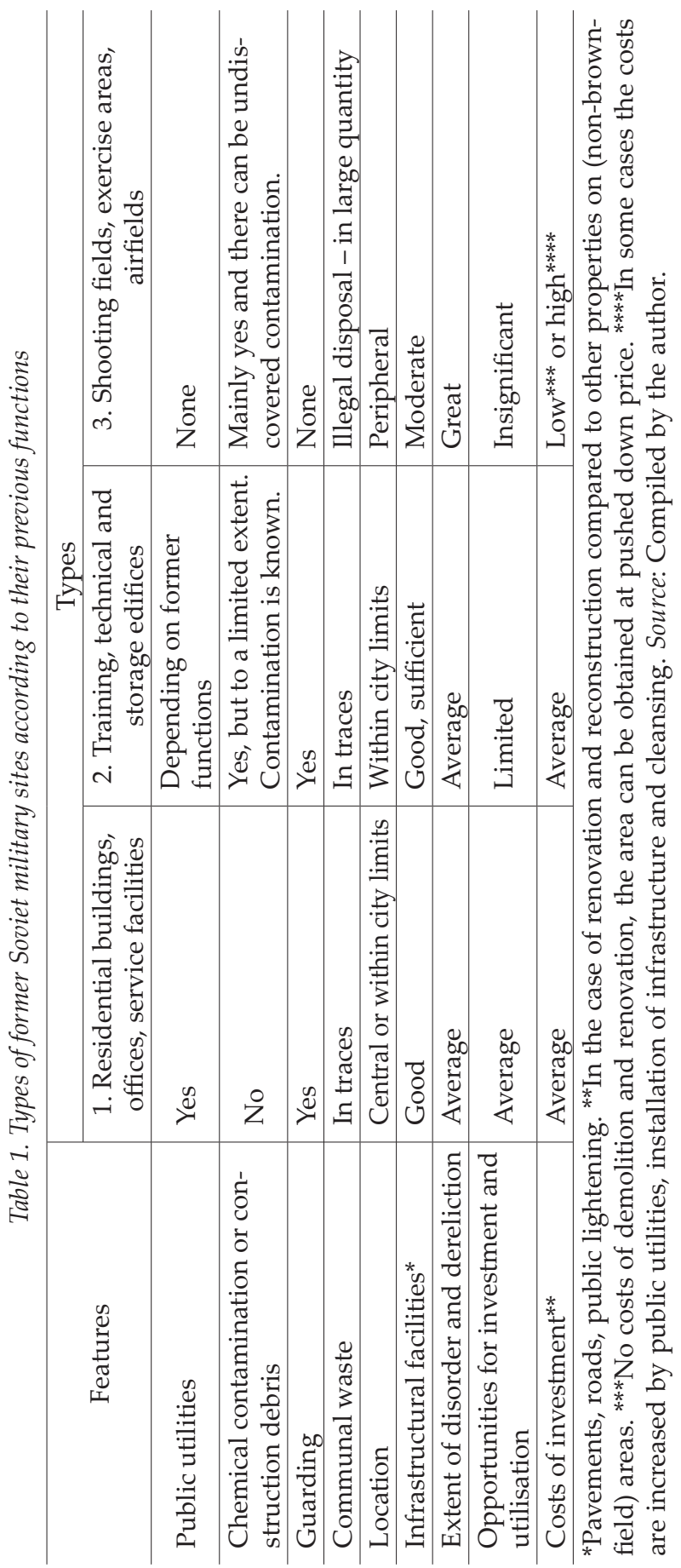

percent of them. Local authorities had no information about 24 percent of the sites. The latter included mostly training areas, bomber shooting fields, airfields and secret sites (e.g. bomb depositories).

Summarising the results, only about half of the municipalities taking part in the survey was able to handle properly the issue of reusing the former Soviet sites, in one way or another e.g. using them for public purposes, or selling them/handing them over to companies that could develop new functions for the sites. Large part of the former Soviet military sites did not go through any reutilisation, and the local municipality did not have among its priorities the functional change of these areas (Photo 4). However, it should also be noted that the latter category included mostly smaller settlements (villages or smaller towns) with excessive greenfield areas for new developments and limited financial resources for urban regeneration. 


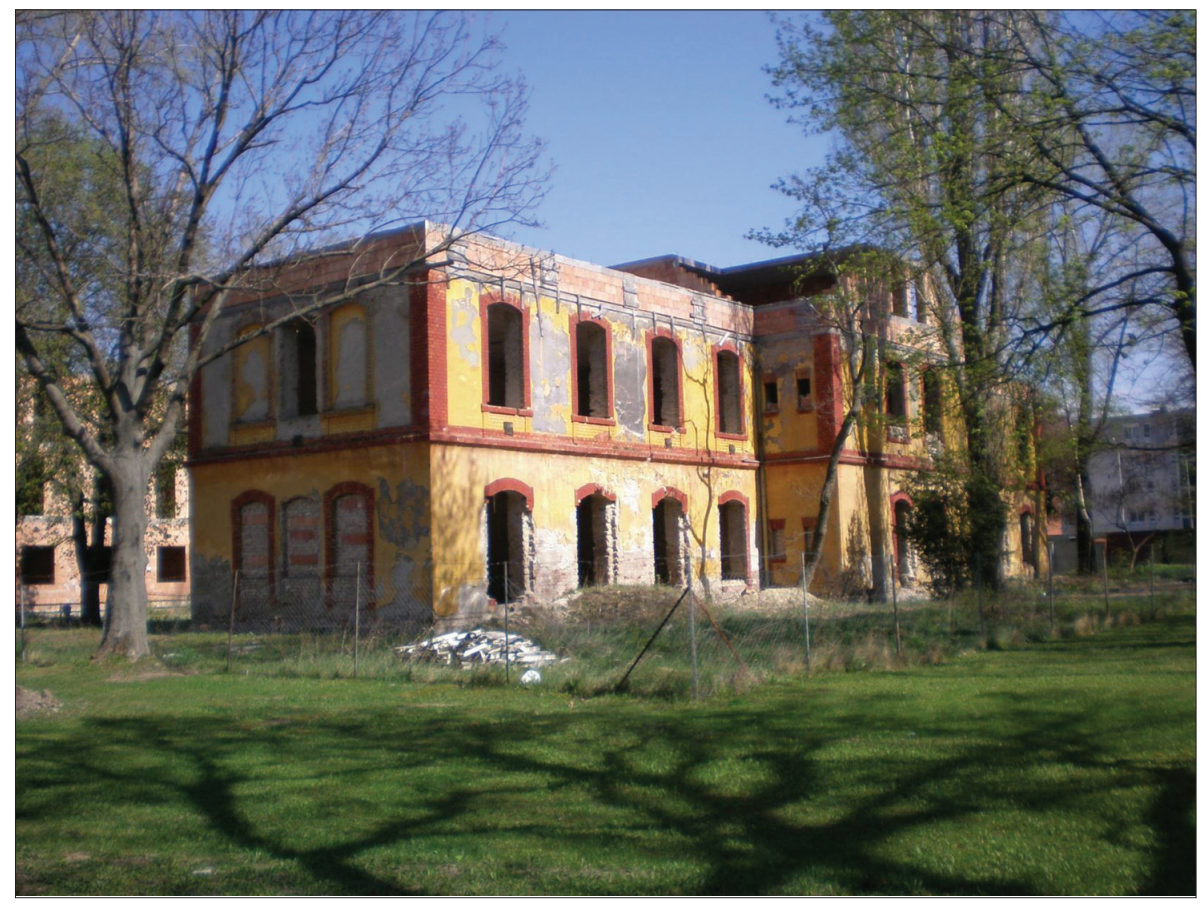

Photo 4. The ruins of a former Soviet kindergarten in Székesfehérvár (Photo: KÁDÁR, K.)

\section{The estimated overall territory of the former Soviet military sites}

On the basis of available information regarding the size of the former Soviet properties, we made estimations on their overall territory. Our results show that the overall territory of the 342 sites was approximately 27,000 hectares (some of these sites were divided into more parts with different functions) (Table 2).

Based on the data collected from local municipalities, 32 percent of all sites had been reused until 2011. Multiplying this data with the mean size (45.5 hectares) of the Soviet military sites calculated on the basis of the surveyed 122 sites, we can conclude that a total area of 5,551 hectares has been rehabilitated in the past 22 years. We identified 96 properties in Budapest and the county seats, which mean 30 percent of all sites. Most of them are located in Budapest (25), whereas Eger, Tatabánya, Kaposvár, Békéscsaba and Salgótarján had no Soviet military properties, while in Pécs, Miskolc and Szekszárd the former Soviet sites were transferred to Hungarian use at the time of the withdrawal of Soviet troops

According to available data and our estimations, around 30 percent (95-100) of the former Soviet military sites are located in the county seats in 


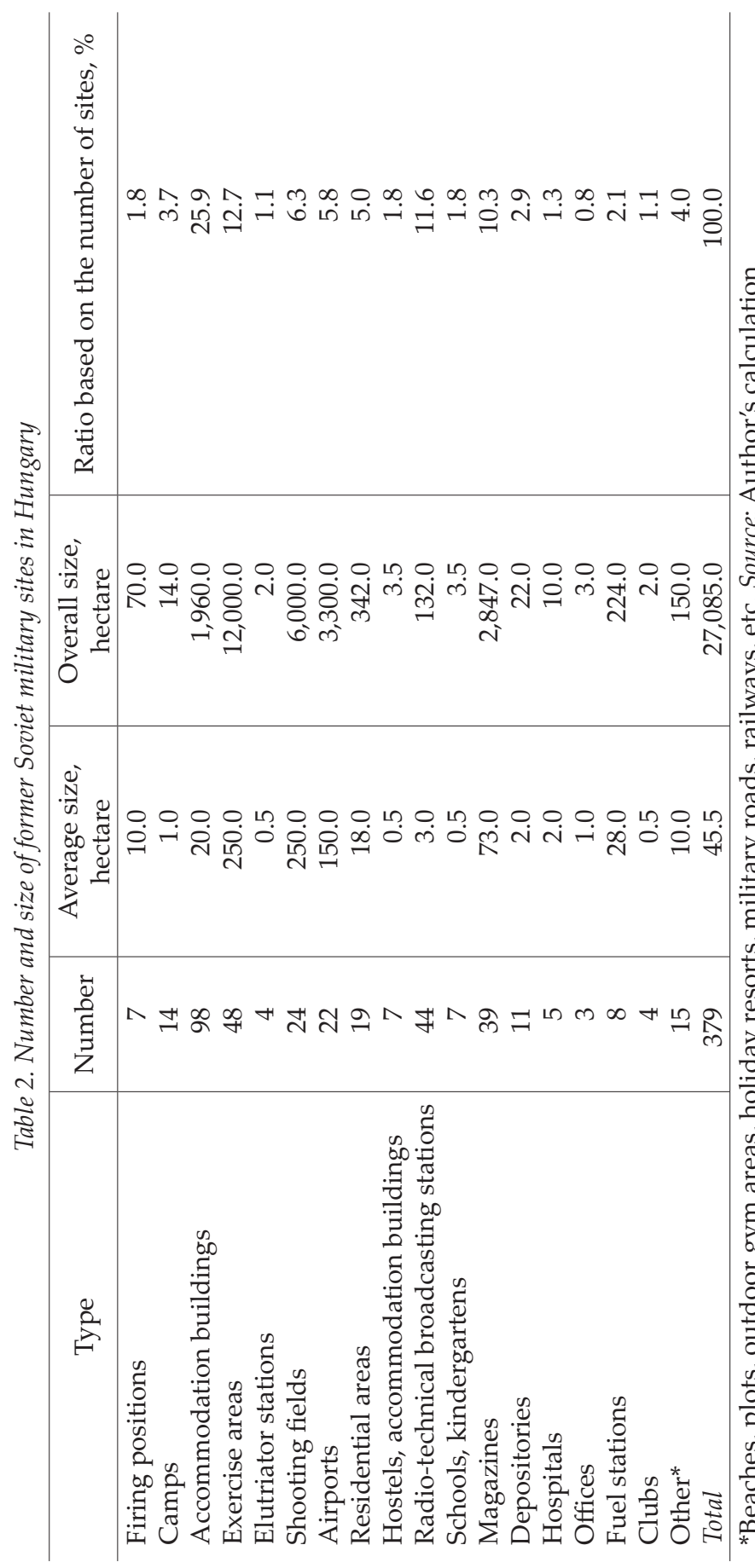

Hungary. Half of these sites (47) are located in the county seats that were selected for further investigation (Szeged, Székesfehérvár, Debrecen, Szolnok, Győr and Kecskemét). The reasons for selecting these county seats are related to the dynamics of their development, the presence of complex urban development programmes, competences and - ideally - financial resources for urban regeneration programmes (KádÁR, K. and Kozma, G. 2011). All types of Soviet military sites summarised in Table 1 occur on their territory and a great number of new functions (institutional, cultural, commercial, residential, etc.) has appeared as an outcome of regeneration. This provided an excellent basis for a comparative analysis of several factors contributing to rehabilitation e.g. economic, social, architectural, and functional. 


\section{Factors determining the success of rehabilitation}

\section{Urban brownfield policy and its influence on regeneration}

The question comes to the fore if the regeneration of Soviet military sites in the selected cities was influenced by the cities' brownfield policies after 1990. Three out of the six investigated cities (Szolnok, Szeged and Debrecen) have a strategy for decreasing the weight of greenfield investments and increasing the role of brownfield regeneration. However, the commitment to regeneration did not start immediately after the withdrawal of Soviet troops, but many years later, usually in the period of the elaboration of integrated urban development strategies. Therefore, it is utterly difficult to define how strong the influence of brownfield strategies on urban development policy was in the earlier period. Every city - independently from its brownfield policy - sold the major part of former Soviet military areas on favourable prices or supported the functional changes by other tools which finally led to the renewal of these areas. However, in the majority of cases re-investment was not resulted by the intervention of the local government, but by the favourable location of the area or the existing infrastructure.

\section{Chances of residential and non-residential utilisation}

In this section we focus on the residential and other, non-business utilisation of Soviet military sites. 18 percent of the Soviet military sites located in the six investigates cities have been reused for residential purposes. The question can be raised if these areas were transformed into residential function because of the growing population figures and new demand for accommodation, or due to other aspects related to economic and social reasons. The average population number of the six analysed cities was 131,887 in 1990, and 133,221 in 2011. Thus, the number of population did not change significantly in these cities during the last 21 years. The population number of Szeged, Kecskemét, Győr and Debrecen grew by a few thousands (mainly in Kecskemét, where the number of residents increased by 11,000, which means a $10 \%$ of growth). The population of Szolnok and Székesfehérvár decreased by a couple of thousands: in Székesfehérvár the population figure dropped by 5.4 percent and in Szolnok by 4.9 percent.

In the light of these figures it is strange enough, that the greatest amount of sites used for residential purposes (40\%) is located in Szolnok, which is followed by Györ (35\%). The changes in the number of population, therefore, does not seem to be related to the intensity of residential regeneration, which was more influenced by the growing demand for cheaper apartments for rent, flats with small floorspace (i.e. for young couples), and the suburban locations (e.g. in Szolnok, Debrecen, Kecskemét). 
The demand for upmarket flats has grown since 2000, consequently some part of the old, tarnished buildings previously used for Hungarian military purposes have been converted to luxury flats in or close to the city centre locations (e.g. in Győr, which has the highest income per capita among the county seats). The area of demolished sites often proved to be suitable for new single family homes or villas (e.g. in Szolnok or Kecskemét) and subdivisions (e.g. in Győr) provided the area was not located far from the centre of the city. In Debrecen, the second largest city in Hungary, only 5 percent of the former sites were converted to housing, mostly some apartments located in the centre of the city. This could be the result of the fact that Debrecen has the greatest size of Soviet military areas and the largest part of it is the former Soviet military airport.

Besides entrepreneurial (commercial and manufacturing) and residential functions, the role of educational, recreational, administrative or public services in the regeneration of Soviet sites was also analysed. Considering the average value of the cities, 13 percent of the total area was converted to educational (cultural) functions and 21 percent to administrative-institutional functions. The educational-cultural function reached its peak in Kecskemét (16\% of the sites) and the administrative-institutional function in Debrecen (30.7\%).

Based on these findings we can draw the conclusion that the ratio of public institutions and educational-cultural functions on former military estates is high especially in those cities where the interest of private sector is low (Kecskemét and Debrecen). Secondly, in these cities there is a huge amount of other (non-brownfield) investment opportunities with lower investments costs. Thirdly, the intervention of private capital was also hampered by the fact that the sites of these cities comprised mainly large building complexes some of them with monument status which limited the possibilities of reuse and renovation.

\section{Economic performance as factor of regeneration}

According to economic indicators (e.g. foreign capital inflow, GDP per capita, number of economic organisations etc.) we set the following rank order among the six selected cities: 1. Győr, 2. Székesfehérvár, 3. Debrecen, 4. Szeged, 5. Kecskemét and 6. Szolnok. Based on our list one would presume that cities with stronger economic performance and more developed industry achieved better results regarding the regeneration of former Soviet military sites, and the utilisation of these sites for economic purposes is also more frequent.

In Győr and Székesfehérvár, the two most developed cities, the share of re-utilised sites is indeed high (100\% and $90 \%$ respectively), however, in the latter case the share of the areas rehabilitated by the local government reaches 33.5 percent, which is only 4.8 percent in Győr and 18.2 percent in Debrecen. The major part of the rehabilitation projects was implemented during the 
initial period (between 1990 and 1995) only in Székesfehérvár, the majority of successful functional changes was realised in Györ in the beginning of 2000s and in Debrecen in the middle of the 1990s.

Out of the new functions the ratio of commercial, industrial and entrepreneurial functions reaches the highest ratio in Debrecen (62\%), while in Győr and Székesfehérvár this ratio is lower (35\% and 50\%). Győr's good economic performance and favourable location in the country makes the city a favourable destination of international and domestic migration, contributing to a higher level of residential utilisation of former Soviet sites. On the other hand, the ratio of areas utilised for economic purposes is significant in Szolnok and Kecskemét ( $40 \%$ and $41 \%$ ), which nearly reaches the figures of Székesfehérvár and Debrecen. In these two cities commercial utilisation plays a more important role (new functions as department stores, shopping malls and retail stores) than the reuse for industrial goals. Therefore, it has not been justified that the success of rehabilitation is mainly determined by the economic power.

The effects of EU funds obtained for urban rehabilitation and brownfield development between 2004 and 2011

All selected cities in our study received financial resources for urban rehabilitation from the EU during the previous and the present budget period, however, none of them received EU funds for the functional change of brownfield areas. Thus, considering the ratio of reutilising Soviet sites and the differences among the cities we could not take it in account as an advantage. EU funds for rehabilitation of Soviet sites either stem from an earlier period (e.g. in Szolnok and Debrecen funds from the PHARE program), or from other EU resources, e.g. from the European Social Fund. Accordingly, we draw the conclusion that EU resources for brownfield rehabilitation have not contributed to the renewal of any of the sites: firstly because the sites did not meet the conditions of application $^{3}$ secondly, the country could not even apply for monetary instruments for the rehabilitation of military sites ${ }^{4}$.

\section{Location within the city}

According to our hypothesis sites with the best regeneration possibilities are located in the centre of the city and they are successfully reused. This is the

${ }^{3}$ In the Regional Operative Program 2.2. (2004-2006) the minimum size of territory for the application should have attained 40 hectares.

${ }^{4}$ Hungary could not apply for EU funds aiming at the conversion of military areas (CONVER, PERIFRA) 
consequence of the increasing demand for both residential and business space in the inner neighbourhoods of larger cities. At the same time sites categorised as Type 1 and Type 2 in our Table 1 are relatively easy to regenerate without significant previous cleaning and arrangement of the area (or demolition of the buildings located there). We suppose that the farther the territory is located from the centre of the city, the less intense its utilisation could be. These sites are hard to regenerate not only due to their location but also their maleficent and poor infrastructure, inadequate condition of buildings.

Available data confirm our initial hypothesis, as unutilised sites situated within the city borders makes up on average only 11 percent of the total territory of Soviet military sites. In three of the cities (Györ, Szolnok, Szeged) there are no unutilised sites, in the other cities their share is between 15 and 20 percent. Altogether 20 sites are located in the suburbs or outside the city limits and the intensity of their reuse varies greatly among the cities $(0 \%$ in Szolnok, 15\% in Szeged, 45\% in Debrecen, 76\% in Kecskemét and 75\% in Székesfehérvár). (Györ does not have such sites.) The high value is striking in Kecskemét and Székesfehérvár as a great number of former Soviet sites are situated in the suburbs (8 and 4), which makes their utilisation more difficult according to our initial hypothesis - if there are other green- and brownfield investment possibilities within the city limits.

Based on our findings we can confirm that the utilisation of sites in the centre of the city was enhanced by their location, while the location did not hamper the utilisation of sites situated in the suburbs or outside the city limits. In the case of the latter not the favourable location, but other factors (such as sufficient infrastructural features, adequate condition of the buildings, the opportunity to start a profitable business enterprise) determined their transformation.

\section{Conclusions}

Former military sites of the Soviet Army became abandoned in large number in Hungary after 1991. As our study demonstrated a number of factors determine the success of rehabilitation of such sites and the role of these factors varies greatly in space and time. According to economic aspects, Győr and Székesfehérvár the two economically most successful cities in Western Hungary are leading the list while the lowest values were found for Szolnok and Kecskemét. But if we handle separately the factors used for analysing economic performance, some of them prove to be able to affect the success of rehabilitations (e.g. the number of functioning enterprises in the city, or the volume of investment in the given region). Differences and similarities in brownfield policy of cities are not relevant. 
Greenfield protection policy is only present in the development documents of Szolnok, Szeged and Debrecen. Based on our analysis, the increase or decrease in population did not influence the ratio of reuse of former Soviet premises for residential function (e.g. Szolnok has the highest ratio of reuse for residential purposes with the greatest decrease of population). In connection with sites used for other than commercial or residential purposes, it has to be highlighted that the ratio of such utilisation (e.g. for public institutions, foundations and cultural purposes) had the highest value in Kecskemét and Debrecen, where private investors showed little interest in utilising these sites. Our survey also revealed that geographical aspects played a greater role in determining the success of rehabilitation. The location within the city or in the inner city was strongly determining the success of regeneration; however $E U$ funds did not contribute considerably to the success of the process.

\section{REFERENCES}

Almássy, E. 2002. Országos Környezeti Kármentesitési Program. Tájékoztató (The National Environmental Remediation Program. Information). Budapest, KVM. http://www. kvvm.hu/szakmai/karmentes/kiadvanyok/okkptajekoztato2002/okkptajek2002.htm

Altman, J., Liebert, W., Neuneck, G. and Scheffran, J. 1998. Dual use and Conversion of Military Related R\&D in Germany. In Conversion of Military RED. Eds. Reppy, J., RotbLat, J., Holdren, J. and Avduyevsky, V., London-New York, Palgrave Macmillan, 163-182.

BARTA, Gy. 2002. A magyar ipar területi folyamatai 1945-2000 (Territorial processes of the Hungarian industry 1945-2000). Budapest-Pécs, Dialóg Campus Kiadó, 272 p.

BARTA, Gy. (ed.) 2003. Rehabilitációs megoldások az európai nagyvárosok rozsdaövezetében (Keys for rehabilitation in the rust belts of some European towns). Pécs-Budapest, MTA Regionális Kutatások Központja, 34 p.

Barta, Gy. 2004. A budapesti barnaövezet megújulási esélyei (Chances of renewal for the brownfield zone in Budapest). Magyarország az ezredfordulón sorozat. Stratégiai tanulmányok a Magyar Tudományos Akadémián. Budapest, MTA Társadalomkutató Központ, 347 p.

BARTA, Gy. (ed.) 2007. Regionális Fejlesztési Operatív Program (ROP 2.2.): A városi területek rehabilitációját célzó intézkedések értékelése (Operational program for Regional Development [ROP 2.2.]: Evaluation of the measures taken to rehabilitate urban territories). Zárótanulmány. Pécs-Budapest, MTA Regionális Kutatások Központja, 151 p.

CABERNET 2004. Scale of Brownfields. http://www.cabernet.org.uk/index.asp?c=1315

Csapody, T. 2000. A gyalogsági aknák Magyarországon. Országjelentés a Landmine Monitor részére (Landmines in Hungary. Country report for Landmine Monitor). Budapest, MTA Politikai Tudományok Intézete, 53 p.

Csendes, L. 1998a. Hadseregtörténet 1989-1990. (History of Army 1989-1990). Új Honvédségi Szemle 3. 51-55.

Csendes, L. 1998b. Hadseregtörténet 1990-1991. (History of Army 1990-1991). Új Honvédségi Szemle 4. 42-52.

ERDôsI, F. 2009. Összeomlás vagy reneszánsz? A hagyományos vasúti közlekedés állapota és kilátásai Kelet-Európában (Collapse or renaissance? The state and chances of the traditional railway transport in Eastern Europe). Tér és Társadalom 23. (2): 1-23. 
Euro-Régió Ház Kft. 2008. Debrecen Megyei Jogú Város Integrált Városfejlesztési Stratégiája (Urban development plan of Debrecen, county seat). Debrecen, Városi Önkormányzat, 220 p.

Ferber, U., Grimski, D., Millar, K. and Nathanail, P. (eds.) 2006. Sustainable Brownfield Regeneration: CABERNET Network Report. Nottingham, University of Nottingham, $132 \mathrm{p}$.

Ganser, R. and Williams, K. 2007. Brownfield Development: Are we using the right targets? Evidence from England and Germany. European Planning Studies 15. (5): 603-622.

Grimski, D. and Ferber, U. 2001. Urban brownfields in Europe. Land Contamination and Reclamation 9. (1): 143-148. http:// eppdocs.books.officelive.comDocuments 09-1-14.pdf.

GYôRI, R. (ed.). 2006. Zöldmezős és barnamezós beruházások a magyar nagyvárosokban (Greenfield and brownfield investments in Hungarian county seats). Budapest, MTA Regionális Kutatások Központja, Kézirat.

Hadtörténelmi Levéltár 2006. A dolgozó népet szolgálom! Forráskiadvány a Magyar Néphadsereg Hadtörténelmi Levéltárban ôrzött irataiból, 1957-1972 (I am serving the working people! Issue of the documents of the Hungarian Army safekeeped by the Archives of Military Histrory, 1957-1972). Budapest, TONYO-GRÁF Nyomdai és Grafikai Stúdió, 306 p.

HHP Contact Tanácsadó Kft (ed.) 2008. Győr Megyei Jogú Város Középtávú Integrált Fejlesztési Stratégiája (Integrated Mid-term City Development Plan of Győr). http://www.gyor. hu/adatok/ivs_kgy_valt_080221.doc

Homor, Gy. 2009. Szovjet csapatkivonás térségünkból (Withdrawal of Soviet troops of our region). Pápa, Jókai Mór Városi Könyvtár Kötészeti és Sokszorosító Műhelye, 336 p.

Horváth, M. 2003. 1956 hadikrónikája (Military chronicle of 1956). Budapest, Akadémiai Kiadó, 482 p.

IUCN 1996. Tanks and Thyme - Biodiversity in Former Soviet Military Areas in Central Europe. Gland, CH - Cambridge, UK. IUCN, 202 p.

Janin, C. and Andres, L. 2008. Les friches: espaces en marge ou marges de maneouvres pour l'aménagement des territoires? Annales de Géographie 5. (63): 62-8.

KÁDÁR, K. 2009. Barnamezős rehabilitáció Nagy-Britanniában és Németországban (Brownfield rehabilitation in Great Britain and Germany). In Regionális Politikai és Gazdaságtani Doktori Iskola Évkönyve 2009. Eds. Buday-Sántha, A., Erdós, K. and Komlósi, É., Pécs, PTE KTK, 120-129.

KÁDÁR, K. 2011a. Barnamezők Magyarországon (Brownfields in Hungary). DETUROPE Central European Journal of Regional Development and Tourism 3. (2): 122-143. http:// www2.zf.jcu.cz/public/projects/cejrdt/img/upload/volumes_22753418.pdf2011

KÁDÁR, K. 2011b. A szovjet katonai objektumok kialakítása, elhagyása és újrahasznosítása hazánkban (Building up, giving up and reutilisation of Soviet military sites in Hungary). Sereg Szemle 2. 133-147.

KÁDÁr, K. and Kozma, G. 2011. Az egykori szovjet katonai területek funkcióváltása Debrecenben (Functional changes in use of the former Soviet military sites in Debrecen). Tér és Társadalom 25. (2): 164-179.

Kälberer, A. (ed.) 2005. The Future lies on Brownfields. Reactivation of Urban Land Reserves. Redevelopment Potentials and Practical. Kempten, Umwelt-Bundesamt, 40 p.

Lux, G. 2009. Az ipar hagyományos terei: a régi ipari térségek (The traditional spaces of industry: old industrial sites). Tér és Társadalom 23. (4): 45-60.

Millar, K. (coord.). 2003. CABERNET: State of the Art-Country Profile Germany. $1^{\text {st }}$ Edition. Nottingham, University of Nottingham. www.cabernet.org.uk

N.N. 1989. Megkezdődött a csapatkivonások gyakorlati előkészítése (The preparation for the withdrawal of troops has been started). Veszprém Megyei Napló 45. 27. p. 
NAGY, Á. (ed.) 2003. Az EU strukturális alapok keretében barnamezős rehabilitációra kiírandó pályázatok szakmai megalapozása (Professional support of applications to be submitted for brownfield rehabilitations stemming form the Structural Funds of the EU). Budapest, VÁTI Kht. 44 p.

Oliver, L., Ferber, U., Grimski, D., Millar, K. and Nathanail, P. 2005. The Scale and Nature of European Brownfields. Nottingham, University of Nottingham, http://www.cabernet. org.uk/resourcefs/417.pdf

RánKI, Gy. 1976. A második világháború története (The History of the World War II.) 2. kiadás. Budapest, Gondolat Kiadó, 651 p.

SÁGI, J. 2006. A logisztikai támogatás keretében megvalósuló ingatlangazdálkodás a honvédelmi szerveknél (Maintenance of real estates with logistic support by the institutions of the Ministry of Defence). Szakdolgozat. Budapest. Zrínyi Miklós Nemzetvédelmi Egyetem, $71 \mathrm{p}$.

Spyra, W. and Katzsch, M. (eds.) 2007. Environmental Security and Public Safety. Dordrecht, NATO Springer, $192 \mathrm{p}$.

Székesfehérvár Megyei Jogú Város Integrált Városfejlesztési Stratégiája 2008. (Urban development plan of Székesfehérvár, county seat, 2008). Székesfehérvár, Városi Önkormányzat, www.szekesfehervar.hu

T.T.T. Bt. 2007. Szeged Megyei Jogú Város Fejlesztési Koncepciója. (Urban Development Conception of Szeged, county seat). Szeged, Városi Önkormányzat, 81 p.

VITUKI Kht. 2005. Az Országos Környezeti Kármentesitési Program Alprogramjai. Tájékoztató összefoglalás az 1997 és 2004. között elvégzett feladatokról (Subprograms of the National Environmental Remediation Program. Information about the task fulfilled between 1997 and 2004). http://www.kvvm.hu/szakmai/karmentes/alprogram/alprogramok.pdf

Vogt, R. (ed.). 2006. The Baltic Sea Region: from a highly militarised area to conversion area. Conversion Handbook for the Baltic Sea Region, Brandenburg. www.conver.net

Woodward, R. 2004. Military Geographies. Malden, USA, - Oxford, UK, - Carlton, AU. John Wiley \& Sons, 212 p. 